\title{
Voices of Gender Discrimination: A Feministic Analysis of Khaled Hosseini's a Thousand splendid suns
}

\author{
*Neenu. C and **Dr. D. Jaisankar
}

1. Ph.D Research Scholar, Department of English, AMET Deemed to be University, Chennai. Tamil Nadu, India, E-Mail: neenuaran@gmail.com

2. Research Supervisor \& Associate Professor, Department of English, AMET Deemed to be University, Chennai. Tamil Nadu, India, E-Mail: dr.jaisankarenglish@ametuniv.ac.in

\begin{abstract}
THE RESEARCH FEATURED BY A BRIEF STUDY OF THE AUTHOR AND HIS NOVEL A THOUSAND SPLENDID SUNS TO UNDERSTAND THE NOVEL. IT IS OUR HOPE THAT THE RESEARCH HERE WILL ELEVATE THE READER TO ENRICH THEIR QUEST FOR CRITICAL APPRECIATION. THE PERSISTENT CONDITIONS OF CONFLICT AND VIOLENCE IN AFGHANISTAN, CONTINUING FOR ALMOST FIFTY YEARS NOW, HAS CAUSED HUGE DESTRUCTION IN TERMS OF HUMAN AND MATERIAL LOSSES. IT HAS ALSO LED TO A RADICAL TRANSFORMATION IN ITS SOCIO-CULTURAL FABRIC ALMOST IRREVERSIBLY. BECAUSE OF THEIR VULNERABLE POSITION IN ITS SOCIETY, THE AFGHAN WOMEN HAVE ENDURED A TOUGH EXISTENCE AS THEY CAME TO GRIPS WITH A DOUBLE SUBJUGATION IN THE FORM OF PATRIARCHAL AUTHORITY AND THE OPPRESSION EMANATING FROM THE PERSISTENT CONDITIONS OF THE CONFLICT. HOWEVER, THERE IS OFTEN A TENDENCY TO CAST AFGHANISTAN AND ITS PEOPLE IN ESSENTIALIST TERMS BOTH IN ACADEMIC AND NON-ACADEMIC ENDEAVOURS. BY CONTEXTUALISING THE AFGHAN WOMEN'S EXPERIENCE IN A SPECIFIC SET OF HISTORICAL, POLITICAL AND SOCIAL FACTORS, THIS WOULD HOPEFULLY OFFER AN ALTERNATIVE VIEW OF THE CONDITION OF AFGHAN WOMEN RATHER THAN THE USUAL STEREOTYPED DESCRIPTIONS. I CONCLUDE THAT THE RESEARCH MAY BE IMPERFECT AS IT IS NOT ABLE TO SATISFY EVERY READERS AND THEIR TASTE.
\end{abstract}

KEY WORDS: A THOUSAND SPLENDID SUNS, AFGHANISTAN WOMEN, KHALED HOSSEINI, AFGHAN WOMEN, OPPRESSION, FEMINIST STYLISTIC ANALYSIS, VOICES OF GENDER DISCRIMINATION.

\section{Introduction}

Afghan Literature rests upon a rich heritage of both oral and written traditions. The two major languages of Afghanistan is Phasto and Dari. It possesses a wealth of literature, unfortunately mostly unstudied, marginalized and known to few. Afghan literature will help to introduce its treasures to broader public. Afghan Literature mostly deals with politics. In poetry, one way or another related to politics. Afghan literature of today is its high degree of responsiveness and immediacy in many other literature a national trauma often demands some sort of "incubation period." The Idol's dust by Zalmai Babakohi, as an example, was written only a month after the destruction of the Bamiyan in March 2001

The Afghan people have become more literate in modern times than they once were, a large amount of the population remains illiterate with $60 \%$ of men and $80 \%$ women not able to read or write. The struggles of the Afghan women are clearly brought out in A Thousand Splendid Suns. Laila's life with parents is a joyous one, but in Mariam's life both with her parents and husband is a pathetic one. Mariam and Laila's life goes predictably rotten. Atlast Mariam is killed by Taliban for the sake of Laila. This novel clearly depicts the lives of the Afghan Women. The reader gets a better picture of women in Afghan through the narration of the character. A Thousand Splendid Suns makes Hosseini a successful writer by selling more than four million copies.

\section{Life of a Married Women}

A persistent theme of A Thousand Splendid Suns is its theme of marriage. In Afghanistan, Women are forced to get married. The bride rarely knows the groom before her wedding. Virginia Woolf says,

It was with a view to marriage that her mind was taught... sketched innocent domestic scenes, but was not allowed to study from the nude; read this book, but was not allowed to read that.... It was with a view to marriage that her body was educated... the streets were shut to her, that the fields that she might preserve her body intact for her husband. In short, the thought of marriage influenced what she said, what she thought, what she did. How could it be otherwise? Marriage was the only profession open to her. (69-70)

Women are taught to be get married. Forced marriage can encompass early or adults who are pushed to marry against their willing because of the wish of their families or religious leaders. Many of the researchers show that 70-80 percent of Afghan women faced forced marriage.

Mariam's mother Nana was not married. Because she believed that the chances of her marriage were destroyed when 'jinn' entered into her body. Jinns are mythical creatures like ghouls and ghosts who are mighty and can make or break people, in Islamic folklore. Nana tells that just before she was going to be married, a jinn is said to have entered her physical body and make her do shameful things. 
Thus her marriage was called off and from that moment on her life became hell.In a country and religious theocracy like Afghanistan the absence of marriage is something shameful and hence Nana's status as a concubine of Jalil has confined her to the outskirts of the city, where she is forbidden to go out for most times and the things she needs are brought to her and her daughter by the sons of Jalil. This bitter experience of the absence of marriage has made Nana a frustrated woman who is cursing everyone and everything all the time. The opening point of the novel is the exposure to Mariam that she is a 'harami'. The word 'harami' means someone who is born out of wedlock, unlawfully according to Islamic traditions. Mariam is called one because her mother Nana had an affair with Jalil and thus became pregnant with Mariam. Somehow they both hid their shame and led an actuality of secrecy and insolvency.

Marriage breaks upon Mariam without warning and absolutely without her consent. After her mother Nana commits suicide it becomes imperative for her father that he marries her off hurriedly as she cannot be left alone. She is not even officially adult and is just a child but she is married to a man over forty, a man named Rasheed who is thirty years older than her. A typical rural Afghan woman marries young and has many children and hardly has a say in the decision of marriage or in the selection of her marriage partner. Nojumi, Mazurana, and Stites states that "Countrywide, 16 percent of girls are married under the age of fifteen, while 52 percent are married by the time they turn eighteen years old" (74).

Women are wishes for greater participation in public life, but the centuries old ethics made them feel that they are in their correct role as dictated by tradition, culture and society. Afghan women's position and role in society as adhering to custom and tradition and do not seek to alter this role. In A Thousand Splendid Suns, Mariam is not willing to marry Rasheed, but her father forces her to marry him. She is totally upset by the behaviour of her father. She even thinks that her father does not love her. The man she married is completely stranger to her.Women are wishes for greater participation in public life, but the centuries old ethics made them feel that they are in their correct role as dictated by tradition, culture and society. Afghan women's position and role in society as adhering to custom and tradition and do not seek to alter this role. In A Thousand Splendid Suns, Mariam is not willing to marry Rasheed, but her father forces her to marry him. She is totally upset by the behaviour of her father. She even thinks that her father does not love her. The man she married is completely stranger to her. Also, he is the age of her father. She fantasized to do her edification, but all her pursuit comes to an end.Though at start things are not so bad and Mariam hopes that she will get something out of marriage, something which had always remained elusive for her mother. But she gets her first taste of horror when Rasheed forcibly has sex with her.
It is a traumatic experience for the little girl, but she is glad that Rasheed behaves well towards her for the rest of the time. After a while, she becomes pregnant and Rasheed's love for her increases, but he makes it clear that he prefers a male child and is hoping that Mariam gives him that. She starts behaving like a proper housewife and cooks and cleans for Rasheed. She tries to please him. However, one day Mariam slips in the bathroom and suffers miscarriage. Rasheed is dismayed and is gloomy and Mariam is very sad. She feels that it is her fault that the child died. But a few weeks after that she becomes pregnant again with Rasheed's child, but she suffers miscarriage again.

She has seven miscarriages in a row and all this while, Rasheed becomes increasingly abusive towards her. He starts beating her black and blue and is neglectful of her needs. It is very understandable now that Rasheed's love for her was just to get a male heir.

Marriage becomes an ordeal for Mariam then as there is no respite from Rasheed and his beatings. She is constantly insulted by him and beaten to no end for no fault of her own. Once when she makes bad daal, Rasheed makes her chew stones which break her teeth, making her cry with agony. Marriage now has become perfect hell for her.

She liabilities herself for her anguish. She feels that she has deceived her mother and went to her father and that is why all of this is happening to her. The jinn equivalence is used here again. Mariam also feels that the jinn steals her babies and thus makes her life miserable. At last married life becomes so miserable for her that she kills her husband to save his second wife Laila and is then murdered by the Islamist Taliban for whom Mariam has committed the most horrible crime imaginable. Thus marriage is a complete disaster for Mariam. Marriage adds to woman's limitation of freedom and she is treated as an object in the hands of men. In Afghanistan, male dominated local culture and the negative impact of decades of war determine the position of women and as a result women remain secluded within the four walls of their homes and have little involvement in public life. Mariam's case, her new life as Rasheed's wife is nowhere near as fairy tale like as father made her seem to be during his weekly visits. Rasheed believes that a man is entitled to rule over his wife. Marriage life takes away her authorization because Rasheed doesn't allow Mariam to go outside without a burqa. Rasheed's behavior towards her is rationally good till Mariam has a miscarriage. After her life become perfect inferno and she spends rest of her life within the four walls.

Marriage becomes a distrustful experience for Mariam. She is not able to indulge the beatings of Rasheed. She is persistently insulted by him. She is beaten to no end for no fault of her own. One day, Mariam makes daal for Rasheed. 
After tasting the daal, Rasheed feels that it is a bad daal. He cruelly makes Mariam to chew stones which break her teeth, making her cry with agony. In the earlier stages Mariam thinks that marriage life is a better-off one, but now it turns into perfect abyss for her.Nojumi Mazurana, Stites clearly states that, marriage between families not between individuals, women is considered as a part of property that belongs to her husband, "For many Afghans, marriage is a part between families, not between individuals. Marriage often involves complex sets of tribal and familial relations, financial exchanges and at times compensation for crimes" (104).Mariam and Laila's cases that they are not asked for their wishes. A depressed and shocked Mariam is compelled by Jalil's wives to marry a man who is more thrice her age. At last married life becomes so miserable for her, after she kills her husband to save his second wife, Laila. She then is murdered by Islamist Taliban for whom Mariam has committed for crime.

Marriage is also a very bad experience for Laila. Laila is a young girl in Mariam's neighbourhood. Laila is in love with Tariq and makes love with him before they are torn apart by cruel circumstances. She does not know that Tariq's love-making has secretly rewarded her with a child. She comes to know that she is pregnant only when she is told that Tariq is dead and she is at the home of Mariam and Rasheed.

Laila is offered by Rasheed that he will marry her and she gets an opportunity to save herself from getting stoned to death on one hand for adultery and on the other hand she gets the opportunity to bring up the child of Tariq, though nobody would know about it.

Laila gives birth to a girl-child and Rasheed starts beating Laila even more than he beats Mariam. but Laila gathers hope for her girl child and for her sake she tries to run away twice. Laila hates Rasheed for the monster that he is. And when he rapes her and she gets pregnant with his child she decides to abort the child, which is a sign of oppression, as she feels that it could be a male child. However, she is not able to do it, and even this male child becomes a sign of hope for her, hope that she will be able to teach something worthwhile to the child. For Laila too marriage is a symbol of oppression. She escapes the bonds of marriage and oppression only with the help of true love, the love that is between her and Tariq. She is misinformed that Tariq died when the bombs hit their homes. However, later Tariq comes back and promises to rescue Laila and he does, although only with the help of Mariam, who kills Rasheed to save Laila.

However, Laila has hope in life, but this hope does not stem from her marriage but from her true love Tariq. It is Tariq who shows her what true love is when she is just a young girl. He is warm, kind and compassionate towards her and promises that he will always love Laila no matter what.
This is proved when Tariq comes back to save Laila even though he is informed that Laila has died earlier.

Growing up together from a young age, they are not only familiar with one another, but also cared for each other deeply. Tariq, with his prosthetic leg, even stood up for Laila and fight off Khadim, a boy who constantly mistreated and teased Laila, when he sprayed urine into her beautiful, blonde hair. As they become teenagers, it is obvious that this friendship has more to offer. I think Laila is more eager to show her affection for Tariq, where as Tariq also feels this way, but did not show it and tried to "play it cool." Eventually, the two kissed for the first time and immediately I, along with the rest of the neighbourhood in Kabul, knew that this relationship is meant to be. The love that Tariq and Laila shared was most definitely true and genuine. (139)

When a rocket falls on the house of Laila while her family is leaving town it kills almost everyone except Laila and Tariq. Her parents die and she takes a long time to recover as she is badly injured in the attack. There is much confusion after the attack and Laila and Tariq are separated. Rasheed already has designs on Laila and hatches a plan to get her.

He pays someone to tell Laila that Tariq dies in the attack. Laila is very sad that her true love died. She resigns herself to fate and sometimes even contemplates suicide. She is housed by Mariam and Rasheed who then marries Laila. Laila does not accept the marriage proposal of Rasheed out of love, but she does that out of the need to hide her pregnancy, the result of her making love with her true love, Tariq, whom she thinks is now dead. However, when the life of Laila has turned to worse under the patronage of Rasheed, Tariq comes back surprising Laila and giving her hope that now things will get better.

After Mariam kills Rasheed, it is Laila's true love which saves her and smuggles her into Pakistan. He is a good man who has absolute love towards the child of Rasheed, Zalmai. He does not differentiate against him. He is also gracious enough to name the coming daughter of his and Laila on the name of Mariam, the woman who makes the reunion of Laila and Tariq possible. However, marriage is not completely a source of pain and frustration in A Thousand Splendid Suns.

Laila's first husband abuses her with no fault. Her life with her first husband is like a hell. As a courageous woman, she still has some hope to find her loved one. She lives her life only for her children. Laila suffers from Rasheed's torture for years then one day Laila's ex-boyfriend Tariq appears whom she knows so far that he was dead, after her life turns into heaven. For Mariam, marriage life is tragic one, but in Laila's case that her second marriage is a blissful one. 
Only the first marriage of Laila is bad. Her second marriage is with Tariq, who is also her true love. Thus in her second marriage, love and marriage coincide for Laila and it becomes a pleasurable experience for her.

\section{Conclusion}

Khaled Hosseini's A Thousand Splendid Suns, published in 2007, is one of his best known works. It chronicles the lives of Mariam and Laila in an orthodox Afghan society. The question of Afghan women as raised in the novel concerned is entangled with the culture and history of the country in such a method that it becomes a phenomenal task to wind up any discussion. In conclusion, Nana, Mariam, and Laila experience many kinds of gender discrimination throughout their lives. In addition, many factors influence their mindsets so that they show different attitudes towards the discrimination they face. Patriarchal ideology forces women, including Nana, to accept the discrimination. However, Mariam and Laila have successfully freed themselves from patriarchal ideology by struggling against the discrimination.

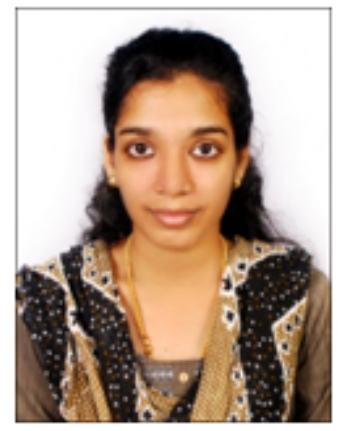

\section{About the Author}

Ms. C. Neenu

Ms. C. Neenu was born in Tamil Nadu, India on October 23, 1994. She got her Bachelor of Arts degree in English Literature from Nirmala College for Women. She got her Master of Arts degree in English from St. Alphonsa College of Arts and Science, Karungal. She got her Bachelor of Education from Siddhartha College of Teacher Education. She completed her Master of Philosophy degree in English Literature from Annai velankanni College, Tholayavattam. Currently She is pursuing her $\mathrm{Ph}$.D research on the topic "Voices of Gender Discrimination: A Feminist Stylistic Analysis of Khaled Husseini's A Thousand Splendid Suns" in AMET University, Chennai, Tamil Nadu, India

\section{Works Cited}

1.Drevitch, Kelly A. The Rights of Afghan Women in Different Eras. Duquesene, 2010.

2.Gerassi, John. Interview with Simon de Beauvoir. Transaction Publisher, 1976.

3.Hosseini, Khaled. A Thousand Splendid Suns. Bloomsberry, 2007.

4.Mansoor, Weeda. Women for Afghan Women: Shuttering Myths and Claiming the Future. Polygrave Macmillan, 2010.

5.Nojumi, Neamatollah, et al. After the Taliban: Life and Security in Rural Afghaistan. Lanhari; Rowman and Littlefield,2009.

6.Otfinoski, Steven. Nations in Transition. Facts on File, 2004

7.Rahimi, W.M. Status of Women: Afghanistan Thailan. UNESCO Principal Regional Office for Asia and the Pacific, 1991.

8.The View from within: An Introduction to New Afghan Literature. 29 Jan 2019. www.words without border.org

9.Abdal Haleem, M.A.S. The Quran. Oxford University Press, 2005.

10.Woolf, Virginia. Three Guineas. The Hogarth Press, 1977.

11. What is Literature/Definition, scope, Types and facts. 22 Dec 2018. www.britanica.com

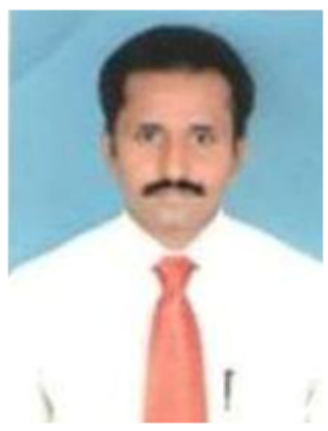

\section{About the Author \\ Dr. D. Jaisankar}

Dr. D. Jaisankar was born in Salem District, Tamil Nadu in India. He got his Bachelor of Arts degree in English Literature from Aringer Anna Government Arts College, Namakkal, Master of Philosophy degree in English Literature from Madras University, Chennai and completed his Ph.D. from Madras University. He has published many research papers in international and national conference proceedings as well as journals. He has done lot of researches in English Literature. He is a recognized supervisor in AMET University, Chennai and guiding many $\mathrm{Ph}$. D Research Scholars. Currently he is serving as an Associate Professor in AMET University, Chennai, Tamil Nadu, India.

Citation: Neenu.C and Dr. D. Jaisankar."Voices of Gender Discrimination: A Feministic Analysis of Khaled Hosseini's A Thousand splendid suns", American Research Journal of English and Literature, Volume 7, Issue No. 1, 2021, pp. 1-4.

Copyright (c) 2021 Neenu.C and Dr. D. Jaisankar. This is an open access article distributed under the Creative Commons Attribution License, which permits unrestricted use, distribution, and reproduction in any medium, provided the original work is properly cited. 